\title{
Pakistan's Balance-of-Payments Crisis and Some Policy Options
}

\section{Moazam Mahmood* and Shamyla Chaudry**}

\begin{abstract}
Neoclassical price theory, and its extension to IMF country advice, argues that balance-of-payments crises such as Pakistan's are better resolved by depreciating the exchange rate, making exports cheaper and imports dearer. We argue that a partial equilibrium analysis of just the tradeable goods market on the current account side ignores the capital market on the capital account side, where an increase in outflows allows no equilibrium value for the exchange rate, through a phenomenon dubbed 'depreciationary expectations', akin to inflationary expectations. This phenomenon will not allow the exchange rate to settle at an equilibrium level, leading to a vicious downward cycle. In such a case, capital controls may well be needed to counter the downward cycle, allowing a return to growth.
\end{abstract}

Keywords: Balance of payments, exchange rates, equilibrium analysis, Pakistan.

JEL Classification: D51, F38.

\section{The Urgency of the Balance-of-Payments Crisis in 2018 and Our Theoretical Argument}

In 2018, Pakistan looked desperately to turning its back on spendthrift growth and development because, at the end of the fiscal year 2017/18, the profligacy of the ancien regime had spawned a current account (CA) deficit of 5.6 percent of GDP and a budget deficit of 6.6 percent of GDP. A due balance of payments (BOP) of USD18 billion, a pressured exchange rate, the halving of reserves to USD9.8 billion, and capital outflows of USD6 billion in the previous year alone required by then the classic recourse to the International Monetary Fund (IMF). Without this multilateral bailout, external payments could not have been met, nor confidence restored in the macro-fundamentals of the economy to allow faltering investment and growth to resume.

\footnotetext{
* Professor Economics, Lahore School of Economics, Pakistan.

** Assistant Professor Economics, Lahore School of Economics, Pakistan.

The authors are grateful to Saniya Jillani, Nayab Kanwal and Muaz Chaudhry at the Lahore School of Economics for their research assistance.
} 
Pakistan's BOP crises have increased in frequency, duration, and intensity since 1990, as Figure 1 shows.

Figure 1: Long-run trend and cyclical variation in CA

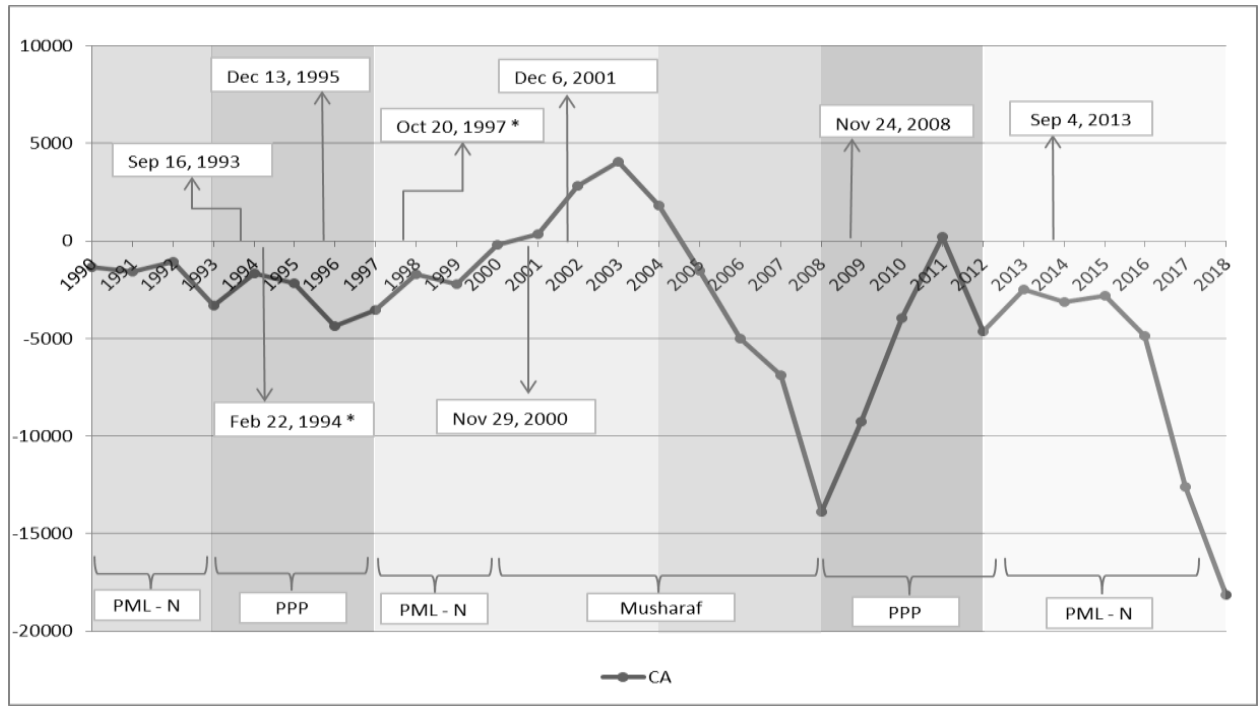

Source: Authors' calculations, based on data from the State Bank of Pakistan.

There have been important preceding diagnostics of these BOP crises. Theoretically, the gap between government revenues and expenditures has to be met by external resources, through a CA deficit (Obstfeld \& Krugman, 2003). Amjad (2019) highlights this link between the CA deficit and budget deficit for Pakistan. In theory, such a framework involves two markets-for domestic goods and tradeable goods.

This article seeks to bring into the analytical framework a third market-for global capital flows. This is done by examining not just the CA, which is the left-hand side of the BOP equation, but also the capital account (KA), which is the right-hand side of the equation.

Thus we have:

$$
\mathrm{CA}=\mathrm{KA}
$$

The BOP always balances as a macro-identity (Obstfeld \& Krugman, 2003). The CA comprises flows of goods, services, and asset incomes in and out of the country for the year. If there is a deficit in the CA on the left-hand side of the equation, it has to be paid for in that year from the KA on the 
right-hand side of the equation. The KA comprises the change in assets-of domestic assets held by foreigners and foreign assets held domestically. Consequently, if there is a CA deficit in a particular year, it must be paid for by a change in capital assets on the KA side. This usually implies liquidating foreign assets held domestically and/or borrowing from foreign sources, public or private. In Pakistan's case, this has usually meant running down the reserves of foreign currencies held by the State Bank of Pakistan (SBP), plus borrowing from foreign sources, contracting multilateral, bilateral, and private debt. Foreign inflows of capital to buy Pakistani assets-foreign direct investment (FDI) and portfolio-could help, but have been meagre. ${ }^{1}$

Here, we aim to systematize in general equilibrium (GE) some of these macro-behavioral relationships.

\section{The Essential Argument}

Confronted by an unsustainable BOP deficit, the standard price solution is to depreciate the exchange rate $e$. This should cheapen exports $\mathrm{X}$, raising them, and make imports $M$ more expensive, lowering them. However, we argue that this standard price solution is based on a partial equilibrium analysis, that is, an analysis of just the left-hand side of equation 1, the CA. A full GE analysis involves also examining the right-hand side of the equation, which is the KA, used to pay for the CA deficit.

A GE framework shows that the price solution of depreciating the exchange rate $e$ will not work on its own for the following reason: we posit that the depreciation of the exchange rate $e$ works analogous to the concept of inflationary expectations. As the exchange rate $e$ depreciates, the CA deficit may persist, according to the growing literature that shows exports to be less price-responsive. A primary argument for this is that exports are usually priced in terms of the foreign buyer's currency, for example, US dollars. So, depreciation of the local currency unit (LCU) with respect to the US dollar will tend not to lower the price of the export because it has already been designated and marketed in US dollars (Gopinath, 2017, 2019).

A second argument for the US dollar prices of exports to remain constant, despite depreciation of the LCU, for a small exporter such as Pakistan, is the immense competition. This makes the country a price taker in the global market rather than a price leader (Rahim, 2020), which will

\footnotetext{
${ }^{1}$ Significant foreign investment in Pakistan and other countries with weak currencies is domestic capital that has fled and is returning in the guise of being foreign.
} 
certainly tend to dampen the depreciation effect. What is essential for our argument is that, as the exchange rate depreciates, the persistence of a CA deficit is both theoretically feasible and, empirically, should be wellobservable. So, a depreciation of the exchange rate, with the persistence of a CA deficit, will create an expectation of further depreciation.

The primary causal factor we are positing for these expectations of depreciation is that, as a result of the initial depreciation, there will be a drop in domestic profitability relative to foreign profitability. This will result, in turn, in an increase in net outflows. As net outflows increase, the exchange rate will depreciate further, leading to a vicious downward cycle, with depreciation and outflows spurring each other on.

\subsection{Theoretical Argument for Depreciation Lowering Domestic Profitability}

This primary causal factor for the phenomenon of expectations of depreciation-of a fall in domestic profitability relative to foreign profitability - can be argued as follows: the impact of depreciation of the exchange rate on domestic profitability can be captured through three effects, described below.

Effect 1

Beginning with a two-share case, of total income can be divided into a profit share and a wage share. So if total income remains constant, a depreciation of the real wage $\mathrm{W}$ by depreciation of the exchange rate $e$ will raise the profit share $\frac{\pi}{Y}$.

Effect 2

However, if a depreciation reduces total income by the same amount as the decrease in in wage share, the profit share also falls. Thus, as a result of depreciation of the exchange rate, we have, in the two-share case, a constancy between the profit share and wage share.

Effect 3

Next, we introduce a third factor share for capital. The capital cost of imported plants and equipment will not decrease with the depreciation of the exchange rate; rather it will appreciate by the extent of the depreciation (assuming the same amount of capital is imported). The rise in the capital 
share by the depreciation of the exchange rate $e$ will further reduce the profit share $\frac{\pi}{Y}$.

We propose that market participants understand and take into account this fall in the profit share before an expected depreciation. So an expected depreciation -dubbed here depreciationary expectations-lead to capital outflows from the country. There are three behavioral reasons for this outflow: (i) declining domestic profitability relative to foreign profitability, (ii) as a precautionary hedge against the expectation of further depreciation of the LCU, the Pakistani rupee, (iii) as a store of value hedge against the expectation of further depreciation of the LCU, the Pakistani rupee. This means that unaccompanied by any other policy instrument, the standard price solution of depreciation will not lead to an equilibrium of the exchange rate.

The policy option of depreciation on its own is self-contradictory because it triggers depreciationary expectations. The initial depreciation causes domestic profitability to drop compared to foreign profitability, leading to increased outflows. The policy option to counter this relative drop in domestic profitability is to raise the domestic interest rate, which raises the cost of borrowing for investment and therefore deters investment.

The resulting restoration of domestic profitability relative to foreign profitability will reduce net outflows, which in turn will reduce further depreciation of the exchange rate. An increase in domestic interest rates can contain the deflationary expectations triggered by an initial depreciation of the exchange rate. However, raising interest rates reduces investment and thus growth, especially for economies with an already very weak investment rate. Moreover, raising interest rates will further weaken growth. A third policy option is therefore implied to fix the BOP crisis, prevent outflows, prevent deflationary expectations, and maintain investment and growth: the option of capital controls, which now has an established policy history of efficacy.

\subsection{Theoretical Argument for Deflationary Expectations in a Price-Led Equilibrium}

The whole point of depreciation is to reduce the CA deficit and reduce pressure on the BOP. However, examining how the KA pays for the CA deficit brings up the role of capital flows. The argument being put forward here is that depreciation of the exchange rate acts like inflationary expectations in its impact on the decision of private agents' capital flows. 
We have net outflows (CF) equal to capital outflows (CO) minus capital inflows (CI):

$$
C F=C O-C I
$$

$\mathrm{CF}$ is a negative function of the domestic interest rate:

$$
\mathrm{CF}=f n(\mathrm{r})
$$

The domestic interest rate acts as a proxy for domestic profitability $\Pi_{d}$ relative to foreign profitability $\Pi_{f}$.

$$
C F=f n\left(\Pi_{d}-\Pi_{f}\right)
$$

CF increases as domestic profitability $\Pi_{d}$ falls below foreign profitability $\Pi_{f}$ in relative terms, in period $t_{1}$ relative to period $t_{0}$.

$$
\text { If } \Pi_{d}<\Pi_{f}, C O \uparrow, C I \downarrow, C F \uparrow
$$

CF decreases as domestic profitability $\Pi_{d}$ rises above foreign profitability $\Pi_{f}$ in relative terms.

$$
\text { If } \Pi_{d}>\Pi_{f}, C O \downarrow, C I \uparrow, C F \uparrow
$$

An initial depreciation of the LCU relative to a foreign currency unit (FCU), for example, the US dollar, implies that demand for the LCU will fall and demand for the US dollar will rise. ${ }^{2}$ This demand for the LCU is actually based on the relative profitability conditions set out in equations (5) and (6). As the LCU depreciates, domestic profitability $\Pi_{d}$ will fall relative to foreign profitability $\Pi_{f}$. More LCUs now need to be earned to equal one US dollar's worth of profits in the domestic economy. According to equation (5), $\mathrm{CO}$ will increase to invest abroad to earn at a relatively higher foreign profitability $\Pi_{f}$. CI will fall again because of relatively higher foreign profitability $\Pi_{f}$. Thus, CF will increase. The relationship between $\mathrm{CF}$ and the exchange rate is given by the behavioral macroeconomic equation (Obstfeld \& Krugman, 2003) below:

$$
N X-f n(e)=C F-f n(r)
$$

\footnotetext{
${ }^{2}$ This is a standard textbook behavioral postulate underlying the demand and supply of LCUs relative to forex, where domestic banks and currency exchanges become the markets.
} 
In equation (7), CF is a negative function of the interest rate, as set out in equation (3), while net exports (NX) are a negative function of the exchange rate $(e)$, as expected by the behavioral price equation. As the exchange rate (e) depreciates, exports should rise, along with NX. But what equation (7) does is to critically link the CA to the KA. NX(e) has to equal $\mathrm{CF}(r)$. The balance of the flows of goods, services and asset incomes in and out of the economy, on the left-hand side of the equation, has to equal the balance of the change in assets-domestic assets held by foreigners and foreign assets held domestically—on the right-hand side of the equation.

This is the textbook identity, that the BOP must always be balanced. A deficit on the CA side of the equation, for instance, in NX(e), has to be paid for by claims on domestically held assets abroad, net, of course, of foreignheld domestic assets in $\mathrm{CF}(r)$. That is, a deficit in the flow of goods, services and asset incomes has to be paid for through the balance of outflows and inflows of claims to assets domestically held abroad and foreign-held domestic assets.

In a comparative statics exercise, this would begin through equation (5). As the exchange rate $e$ depreciates, domestic profitability falls below foreign profitability in relative terms, as discussed above. This will induce $\mathrm{CO}$ to increase and $\mathrm{CI}$ to decrease, increasing $\mathrm{CF}$ all in order to take advantage of the relative rise in foreign profitability.

As $\mathrm{CF}$ increases, it will depreciate the exchange rate in a vicious loop for two reasons. First, the demand for the LCU will fall relative to, for example, the US dollar. This will weaken the exchange rate of the LCU to the US dollar. Second, the increased CF will also reduce the demand for domestic assets and their price. The textbook argument is that, as the demand for domestic assets drops, so does their price level relative to the foreign price level-which is the exchange rate. This general reduction in the price level will also depreciate the exchange rate $e$ further.

This argues that equation (7) morphs into:

$$
C F=f n(e, r)
$$

Our postulate is that $\mathrm{CF}$ becomes a negative function of both the exchange rate $e$ and the interest rate $r$. Thus, equation (8) expects a vicious downward cycle of an initial drop in exchange rates, reducing profitability $r$, which leads to an increased $\mathrm{CF}$, thereby reducing the demand for domestic assets, both of which in turn lower the exchange rate $e$ further. The exchange 
rate $e$ and the profitability rate $r$ can fall endlessly downward, with no automatic solution of a price equilibrium. This illustrates the case for depreciationary expectations under ceteris paribus conditions, with no automatic solution in the form of a price equilibrium.

\subsection{Countering Deflationary Expectations in a Price-Led Model}

Reestablishing equilibrium then requires cutting through this vicious downward cycle by raising the profit rate through the interest rate $r$. A depreciation in the exchange rate $e$ can be prevented from decreasing domestic profitability relative to foreign profitability, $\Pi_{d}<\Pi_{f}$, as in equation (5), by raising the interest rate $r$. The interest rate $r$ here represents the base rate of domestic returns for a supply of investible funds, domestic or CI. This will raise domestic profitability relative to foreign profitability, $\Pi_{d}>\Pi_{f}$, as in equation (6), reducing $\mathrm{CO}$, raising $\mathrm{CI}$, and therefore reducing $\mathrm{CF}$. As the demand for the LCU increases relative to, say, the US dollar, this will strengthen the exchange rate of the LCU to the US dollar. This is the logic of equation (7) - that the interest rate $r$ and exchange rate $e$ move together. Thus, raising the interest rate $r$ will raise the exchange rate $e$, thereby preventing depreciationary expectations.

A cautionary note needs to be sounded in summing up this theoretical exercise. Equation (7) links the KA with the CA as a traditionally given identity, but that does not mean that the KA is not causally linked to the CA. In fact, the CA is a function of the exchange rate, while the KA is a function of the interest rate. The $\mathrm{KA}$ - primarily reserves and interest ratesis used to influence the CA's exchange rate. True, the interest rate is a monetary policy variable, but must be viewed as a major KA policy instrument. Reserves, of course, are an intrinsic KA instrument and are used critically to control the exchange rate on the CA side.

\subsection{Pakistan's Case}

This theoretical framework is applied to Pakistan's case. Pakistan's BOP crises have been compounded since 1990. Preceding diagnostics for Pakistan, such as Amjad (2019), highlight the link between the CA deficit and the budget deficit. The gap between government revenues and expenditures needs to be met by means of external resources, through a CA deficit (Obstfeld \& Krugman, 2003). Such a framework involves two markets-for domestic goods and tradeable goods. This paper brings into the analytical framework, a third market-that for global capital flows. This 
is done by examining not just the $\mathrm{CA}$, which is the left-hand side of the BOP equation, but also the $\mathrm{KA}$, which is the right-hand side of the equation.

As seen above, the BOP always balances as a macro-identity (Obstfeld \& Krugman, 2003). As explained above, the CA comprises flows of goods, services, and asset incomes in and out of the country for the year. If there is a deficit in the CA, on the left-hand side of the equation, it has to be paid for in that year from the KA, on the right-hand side of the equation. The KA comprises changes in assets-of domestic assets held by foreigners and foreign assets held domestically. If there is a CA deficit in a particular year, it must be paid for by a change in capital assets on the KA side. In Pakistan's case, this has usually meant running down reserves of foreign currencies held by the SBP plus borrowing from foreign sources, that is, contracting multilateral, bilateral and private debt.

Confronted by an unsustainable BOP deficit in Pakistan's case, the standard price solution has been to depreciate the exchange rate $e$. What is essential for our argument is that, as the exchange rate is depreciated, the persistence of a CA deficit is both theoretically feasible and empirically well-observed, especially in the case of Pakistan. A depreciation of the exchange rate with the persistence of a CA deficit will create an expectation of further depreciation.

Our theoretical framework argues that the policy option of depreciation on its own is self-contradictory, because it triggers depreciationary expectations. The initial depreciation causes domestic profitability to drop compared to foreign profitability, leading to increased outflows. The policy option to counter this relative drop in domestic profitability is to raise the domestic interest rate. The resulting restoration of domestic profitability relative to foreign profitability will reduce net outflows and, in turn, reduce further depreciation of the exchange rate.

An increase in domestic interest rates can contain the depreciationary expectations triggered by an initial depreciation of the exchange rate. However, raising interest rates reduces investment and thus growth, especially for an economy such as Pakistan's with an already very weak investment rate of 16 percent of GDP. Raising interest rates will further weaken growth below its already anemic 4 percent per annum. A third policy option is therefore implied to fix the BOP crisis, prevent outflows, prevent depreciationary expectations, and maintain investment and growth: the option of capital controls which, in Pakistan, has been neglected of late. 


\subsection{Hypotheses for Pakistan's Case}

In Pakistan's case, we hypothesize that depreciationary expectations should be observable for the period 1990 to the fiscal year 2017/18, for which we have been able to build a consistent series for these variables, using SBP data and in collaboration with the central bank.

These hypotheses require two caveats-one theoretical, one empirical. The first caveat is a theoretical one, required for the conceptual framework posited above to be applicable to Pakistan's institutional context. The first, as argued earlier, is that depreciationary expectations would apply in a purely price-led equilibrium, giving market-determined exchange rates. In a country such as Pakistan, with its long history of managed pegs to the US dollar, prior to the float in the fiscal year 2018/19 (the period under examination), the market-determined exchange rate would be expected to pressure the SBP to adjust the managed peg accordingly, if not fully, but in that direction.

This assumption about the behavior of the SBP to adjust the peg in the same direction as a market-determined exchange rate, also allows us to posit the behavior of investors of capital as if they were operating in a purely price-led equilibrium giving market-determined exchange rates.

The second caveat is an empirical one, that a purely price-led equilibrium, giving market-determined exchange rates, rests on the required condition of ceteris paribus. Such a purely price-led equilibrium would not apply strictly to a real economy such as Pakistan's, which would have used interest rate $(r)$ increases, and/or growth of money supply reductions, to counter exchange rate depreciation (e), as in Section 2.3 above.

Nevertheless, we would not expect interest rates to have been raised sufficiently in Pakistan's case to completely counter depreciationary expectations. Interest rates are the cost of borrowing, and thus too large an increase would dampen investment and growth in an already low-growth economy, as will be elaborated in the policy section below. Given such a policy environment, attempting to balance BOP concerns with growth tradeoffs, we would still expect to observe depreciationary expectations. Accordingly, our hypotheses will be the following:

H1: Depreciationary expectations will be indicated by the long-run trend of depreciation of the exchange rate being positively correlated with capital outflows from Pakistan. 
Capital outflows can be defined behaviorally in two ways:

- A narrower definition will include all outflows abroad for investment to obtain financial yield, and for consumption motives. Therefore, a long-run trend of depreciation will be positively correlated with this narrow definition of capital outflows.

- A broader definition would add all outflows as hedges against expected depreciation for store-of-value and precautionary motives. These two motives require including all foreign currency holdings in Pakistan, that is, holders of rupee balances who exchange them for US dollars. The argument is that foreign currency deposits reduce the demand for rupees and increase the demand for foreign currency, which will reduce the exchange rate, leading in turn to higher capital outflows.

Therefore, a long-run trend of depreciation will be positively correlated with foreign currency deposits and the broader definitions of capital outflows.

H2: In a price-led equilibrium model, depreciation of the exchange rate will not find equilibrium. Equilibrium implies some cyclicality of the exchange rate, or at least some stationarity after downfalls. In Pakistan's case, lack of equilibrium will lead to a secular long-run decline in the exchange rate over time.

H3: Depreciationary expectations will increase capital outflows from Pakistan, which in turn will reduce domestic investment in Pakistan. Hence, in the long run, depreciation will be negatively correlated with the share of private investment in Pakistan.

H4: Deflationary expectations will increase capital outflows from Pakistan, which in turn will reduce domestic savings in Pakistan. Hence, in the long run, depreciation will be negatively correlated with the share of private savings in GDP in Pakistan.

Savings in Pakistan are not estimated empirically from national income accounts data, but as a residual from investment and capital inflows. Therefore, savings and investment may not be statistically independent and will be correlated. However, capital inflows are statistically independent, therefore making savings not perfectly correlated with investment. Therefore, $\mathrm{H} 4$ becomes worth testing for savings. 


\section{Estimation of Outflows}

The key variable to be estimated is capital outflows from the KA. The narrow definition of this variable is the problematic one because the broader definition simply takes this narrower definition, and adds to it resident foreign currency accounts (RFCAs), which are estimated by the SBP. The narrow definition of capital outflows must be based on the theoretical framework. The argument is that domestic outflows are based on the relative profitability of investing in the country as opposed to investing abroad. Therefore, the definition of capital outflows must begin with domestic outflows for investment abroad.

- The components of domestic outflows for investment abroad all come from the KA. This is consistent with the theoretical framework adopted above, that depreciation on the CA side leads to outflows on the KA side, triggering further depreciation. It also causes domestic asset price deflation, triggering in turn further depreciation. This phenomenon, being posited here as depreciationary expectations, leads to lack of equilibrium in the exchange rate in a long-run vicious spiral downward of depreciation and capital outflows.

- A further case can be made for adding to capital outflows from the KA side, outflows of income from the CA side of the equation, which comprises foreign-held domestic asset yields being repatriated. This is called the primary income balance from the CA. Its repatriation abroad pressures the exchange rate downward and detracts from FDI and portfolio investment from abroad.

Then domestic plus foreign-held capital outflows capture more comprehensively all capital and income flows abroad. These comprise four major components according to the SBP's established accounting framework. These are:

Domestic outflows for investment from the financial account (FA)

$$
=
$$

Direct investment abroad

+ Portfolio investment abroad

+ Net incurrence of assets

+ Net outflows of primary income from the CA

$=$ Primary income balance 
$=$ Total net outflows from Pakistan

Table 1 estimates total net outflows from Pakistan for the fiscal year 2018 at USD5.4 billion. This is well in keeping with the then SBP governor's pronouncement that approximately USD6 billion had flowed out of Pakistan in the fiscal year 2018. ${ }^{3}$ The series for total net outflows, estimated from the SBP's database, and in collaboration with the bank, is given in Table 2. To estimate the broader definition of capital, RFCAs are added to domestic outflows for investment from the FA. These RFCAs and the broader definition of capital outflows are given in Table 3.

Table 1: Estimating total net outflows from Pakistan (USD million)

\begin{tabular}{lc}
\hline Year & $\mathbf{2 0 1 8}$ \\
\hline Total net outflows & 5,454 \\
Net outflows from FA & 172 \\
Direct investment abroad & 10 \\
Portfolio investment abroad & -48 \\
Net incurrence of assets & 210 \\
Net outflows from CA & 5,282 \\
\hline
\end{tabular}

Source: Authors' calculations, based on data from the State Bank of Pakistan.

\footnotetext{
${ }^{3}$ Statement by the SBP governor, Tariq Bajwa, at the Lahore School of Economics board of governors meeting in 2018.
} 
Table 2: Total net outflows (USD million)

\begin{tabular}{|c|c|c|c|c|c|c|}
\hline Year & $\begin{array}{c}\text { Direct } \\
\text { investment } \\
\text { abroad }\end{array}$ & $\begin{array}{c}\text { Portfolio } \\
\text { investment } \\
\text { abroad } \\
\text { (B) }\end{array}$ & $\begin{array}{c}\text { Net } \\
\text { acquisition } \\
\text { of financial } \\
\text { assets } \\
\text { (C) }\end{array}$ & $\begin{array}{c}\begin{array}{c}\text { Net } \\
\text { outflows } \\
\text { from FA }\end{array} \\
(\mathrm{D}=\mathrm{A}+\mathrm{B}+\mathrm{C})\end{array}$ & $\begin{array}{c}\text { Net outflow } \\
\text { from CA } \\
\text { (primary } \\
\text { income) } \\
\text { (E) }\end{array}$ & $\begin{array}{l}\text { Total net } \\
\text { outflows }\end{array}$ \\
\hline 1990 & 12 & 0 & -272 & -260 & 878 & 618 \\
\hline 1991 & 7 & 0 & -448 & -441 & 941 & 500 \\
\hline 1992 & 8 & 0 & -291 & -283 & 1,123 & 840 \\
\hline 1993 & -4 & 0 & -702 & -706 & 1,389 & 683 \\
\hline 1994 & -6 & 0 & -181 & -187 & 1,447 & 1,260 \\
\hline 1995 & 3 & 0 & -140 & -137 & 1,359 & 1,222 \\
\hline 1996 & -4 & 0 & 140 & 136 & 1,804 & 1,940 \\
\hline 1997 & -18 & 0 & 64 & 46 & 2,203 & 2,249 \\
\hline 1998 & 29 & 0 & -367 & -338 & 2,188 & 1,850 \\
\hline 1999 & 44 & 0 & -34 & 10 & 1,803 & 1,813 \\
\hline 2000 & -1 & 549 & -449 & 99 & 1,972 & 2,071 \\
\hline 2001 & 37 & 140 & -291 & -114 & 2,203 & 2,089 \\
\hline 2002 & 2 & 491 & 236 & 729 & 2,207 & 2,936 \\
\hline 2003 & 27 & 0 & 434 & 461 & 2,211 & 2,672 \\
\hline 2004 & 45 & -3 & -546 & -504 & 2,207 & 1,703 \\
\hline 2005 & 66 & -11 & $-1,235$ & $-1,180$ & 2,386 & 1,206 \\
\hline 2006 & 71 & -22 & -209 & -160 & 2,667 & 2,507 \\
\hline 2007 & 114 & 5 & -758 & -639 & 3,582 & 2,943 \\
\hline 2008 & 75 & 5 & 32 & 112 & 3,923 & 4,035 \\
\hline 2009 & 25 & 1,073 & 560 & 1,658 & 4,407 & 6,065 \\
\hline 2010 & 76 & 65 & -11 & 130 & 3,282 & 3,412 \\
\hline 2011 & 44 & 7 & -920 & -869 & 3,017 & 2,148 \\
\hline 2012 & 77 & 32 & -9 & 100 & 3,245 & 3,345 \\
\hline 2013 & 198 & 99 & 314 & 611 & 3,669 & 4,280 \\
\hline 2014 & 128 & -23 & -211 & -106 & 3,955 & 3,849 \\
\hline 2015 & 73 & -41 & -71 & -39 & 4,599 & 4,560 \\
\hline 2016 & 19 & 100 & 96 & 215 & 5,347 & 5,562 \\
\hline 2017 & 86 & -1 & 1,180 & 1,265 & 5,048 & 6,313 \\
\hline 2018 & 10 & -48 & 210 & 172 & 5,282 & 5,454 \\
\hline
\end{tabular}

Source: Authors' calculations, based on data from the State Bank of Pakistan. 
Table 3: RFCAs, investment and saving as a percentage of GDP, and exchange rates

\begin{tabular}{|c|c|c|c|c|c|c|c|}
\hline Year & $\begin{array}{c}\text { Exchange } \\
\text { rate } \\
\text { (PKR to } \\
\text { USD1) }\end{array}$ & $\begin{array}{l}\text { Dep base } \\
\text { year } 1990\end{array}$ & RFCA & $\begin{array}{l}\text { Total net } \\
\text { outflows }\end{array}$ & $\begin{array}{c}\sum \text { of total } \\
\text { net } \\
\text { outflows } \\
\text { and RFCA } \\
(A+B) \\
\end{array}$ & $\begin{array}{l}\text { Gross total } \\
\text { investment } \\
\text { as } \% \text { of } \\
\text { GDP }\end{array}$ & $\begin{array}{l}\text { Domestic } \\
\text { savings as } \\
\% \text { of GDP }\end{array}$ \\
\hline 1990 & 21.71 & $0 \%$ & 0 & 618 & 618 & $18.9 \%$ & $11.7 \%$ \\
\hline 1991 & 23.80 & $10 \%$ & 399 & 500 & 899 & $18.5 \%$ & $12.7 \%$ \\
\hline 1992 & 24.84 & $14 \%$ & 1,731 & 840 & 2,571 & $19.9 \%$ & $16.6 \%$ \\
\hline 1993 & 25.96 & $20 \%$ & 2,360 & 683 & 3,043 & $20.5 \%$ & $14.4 \%$ \\
\hline 1994 & 30.16 & $39 \%$ & 3,054 & 1,260 & 4,314 & $19.4 \%$ & $15.9 \%$ \\
\hline 1995 & 30.85 & $42 \%$ & 3,406 & 1,222 & 4,628 & $18.6 \%$ & $14.2 \%$ \\
\hline 1996 & 33.57 & $55 \%$ & 4,348 & 1,940 & 6,288 & $19.4 \%$ & $12.4 \%$ \\
\hline 1997 & 38.99 & $80 \%$ & 5,716 & 2,249 & 7,965 & $18.1 \%$ & $12.8 \%$ \\
\hline 1998 & 43.20 & $99 \%$ & 6,449 & 1,850 & 8,299 & $17.9 \%$ & $15.4 \%$ \\
\hline 1999 & 46.79 & $116 \%$ & 2,584 & 1,813 & 4,397 & $15.7 \%$ & $13.1 \%$ \\
\hline 2000 & 51.77 & $138 \%$ & 2,173 & 2,071 & 4,244 & $15.8 \%$ & $15.8 \%$ \\
\hline 2001 & 58.44 & $169 \%$ & 2,638 & 2,089 & 4,727 & $17.2 \%$ & $16.9 \%$ \\
\hline 2002 & 61.43 & $183 \%$ & 2,563 & 2,936 & 5,499 & $16.6 \%$ & $18.1 \%$ \\
\hline 2003 & 58.50 & $169 \%$ & 2,156 & 2,672 & 4,828 & $16.7 \%$ & $17.6 \%$ \\
\hline 2004 & 57.57 & $165 \%$ & 2,531 & 1,703 & 4,234 & $16.6 \%$ & $16.4 \%$ \\
\hline 2005 & 59.36 & $173 \%$ & 3,038 & 1,206 & 4,244 & $19.1 \%$ & $15.4 \%$ \\
\hline 2006 & 59.86 & $176 \%$ & 3,266 & 2,507 & 5,773 & $22.1 \%$ & $15.7 \%$ \\
\hline 2007 & 60.63 & $179 \%$ & 3,419 & 2,943 & 6,362 & $22.9 \%$ & $15.6 \%$ \\
\hline 2008 & 62.55 & $188 \%$ & 4,212 & 4,035 & 8,247 & $21.6 \%$ & $11.5 \%$ \\
\hline 2009 & 78.50 & $262 \%$ & 3,572 & 6,065 & 9,637 & $17.5 \%$ & $9.8 \%$ \\
\hline 2010 & 83.39 & $284 \%$ & 4,142 & 3,412 & 7,554 & $15.8 \%$ & $9.3 \%$ \\
\hline 2011 & 85.56 & $294 \%$ & 4,382 & 2,148 & 6,530 & $14.1 \%$ & $9.7 \%$ \\
\hline 2012 & 89.27 & $311 \%$ & 4,930 & 3,345 & 8,275 & $14.9 \%$ & $7.7 \%$ \\
\hline 2013 & 96.73 & $346 \%$ & 5,324 & 4,280 & 9,604 & $14.2 \%$ & $9.0 \%$ \\
\hline 2014 & 102.86 & $374 \%$ & 5,827 & 3,849 & 9,676 & $14.6 \%$ & $9.8 \%$ \\
\hline 2015 & 101.29 & $367 \%$ & 5,901 & 4,560 & 10,461 & $15.7 \%$ & $10.1 \%$ \\
\hline 2016 & 104.24 & $380 \%$ & 5,634 & 5,562 & 11,196 & $15.7 \%$ & $8.7 \%$ \\
\hline 2017 & 104.67 & $382 \%$ & 6,261 & 6,313 & 12,574 & $16.1 \%$ & $8.2 \%$ \\
\hline 2018 & 109.84 & $406 \%$ & 7,551 & 5,454 & 13,005 & $16.4 \%$ & $7.5 \%$ \\
\hline
\end{tabular}

Source: Authors' calculations, based on data from the State Bank of Pakistan.

\section{Some Empirical Results}

This section presents the study's empirical results for Pakistan's CA and $\mathrm{KA}$, and depreciation and outflows.

\subsection{Pakistan's CA Problems and Financing from the $K A$}

Figure 1 and Table 4 show that, for the last 30 years, Pakistan's CA has been under pressure and in deficit for most of this period, except for five years, from 2001 to 2004, and 2011. 1990 to 1993 saw small but increasing CA deficits of under USD5 billion. Figure 1 shows that a succession of IMF 
support programs in 1993,1994,1995, and 1997, reduced the deficits shortterm to near-balance by 2000. Another two IMF programs, in 2000 and 2001, appear to have contributed to the only CA surplus from 2000 to 2004.

Table 4: Decomposition of the CA (USD million)

\begin{tabular}{|c|c|c|c|c|c|c|c|}
\hline Year & $(A+B+C)$ & $\begin{array}{l}\text { Balance on } \\
\text { trade in } \\
\text { goods and } \\
\text { services } \\
\text { (A) }\end{array}$ & $\begin{array}{c}\text { Balance on } \\
\text { primary } \\
\text { income }\end{array}$ & $\begin{array}{c}\text { Balance on } \\
\text { secondary } \\
\text { income }\end{array}$ & $\begin{array}{c}\text { Change in } \\
\text { reserves } \\
\text { and related } \\
\text { items }\end{array}$ & $\begin{array}{c}\text { Accumulat } \\
\text { ed reserves } \\
\text { (SBP + } \\
\text { banks + } \\
\text { gold) }\end{array}$ & $\begin{array}{l}\text { Accumulat } \\
\text { ed reserves } \\
\text { (SBP only) }\end{array}$ \\
\hline 1990 & $-1,353$ & $-3,223$ & -878 & 2,748 & 377 & 1,451 & - \\
\hline 1991 & $-1,578$ & $-3,388$ & -941 & 2,751 & 6 & 1,390 & - \\
\hline 1992 & $-1,049$ & $-3,337$ & $-1,123$ & 3,411 & 130 & 1,761 & - \\
\hline 1993 & $-3,327$ & $-4,626$ & $-1,389$ & 2,688 & -589 & 1,369 & - \\
\hline 1994 & $-1,651$ & $-2,908$ & $-1,447$ & 2,704 & 1,585 & 3,337 & - \\
\hline 1995 & $-2,163$ & $-3,562$ & $-1,359$ & 2,758 & 238 & 3,730 & - \\
\hline 1996 & $-4,348$ & $-5,149$ & $-1,804$ & 2,605 & -431 & 3,521 & - \\
\hline 1997 & $-3,557$ & $-4,601$ & $-2,203$ & 3,247 & $-1,032$ & 1,977 & - \\
\hline 1998 & $-1,701$ & $-2,943$ & $-2,188$ & 3,430 & -306 & 1,737 & 935 \\
\hline 1999 & $-2,235$ & $-3,279$ & $-1,803$ & 2,847 & 824 & 2,922 & 1,673 \\
\hline 2000 & -217 & $-2,234$ & $-1,972$ & 3,989 & 72 & 2,766 & 997 \\
\hline 2001 & 326 & $-2,208$ & $-2,203$ & 4,737 & 1,001 & 3,810 & 1,689 \\
\hline 2002 & 2,833 & -733 & $-2,207$ & 5,773 & 2,792 & 7,065 & 4,337 \\
\hline 2003 & 4,070 & -361 & $-2,211$ & 6,642 & 5,239 & 11,472 & 9,529 \\
\hline 2004 & 1,811 & $-2,595$ & $-2,207$ & 6,613 & 904 & 13,155 & 10,564 \\
\hline 2005 & $-1,534$ & $-7,807$ & $-2,386$ & 8,659 & -293 & 13,338 & 9,805 \\
\hline 2006 & $-4,990$ & $-12,871$ & $-2,667$ & 10,548 & 977 & 14,354 & 10,765 \\
\hline 2007 & $-6,878$ & $-13,881$ & $-3,582$ & 10,585 & 3,577 & 18,890 & 14,333 \\
\hline 2008 & $-13,874$ & $-21,427$ & $-3,923$ & 11,476 & $-5,365$ & 13,436 & 8,745 \\
\hline 2009 & $-9,261$ & $-16,008$ & $-4,407$ & 11,154 & $-3,056$ & 13,971 & 9,527 \\
\hline 2010 & $-3,946$ & $-13,226$ & $-3,282$ & 12,562 & 1,266 & 17,921 & 13,112 \\
\hline 2011 & 214 & $-12,456$ & $-3,017$ & 15,687 & 2,492 & 20,941 & 15,662 \\
\hline 2012 & $-4,658$ & $-18,957$ & $-3,245$ & 17,544 & $-3,275$ & 16,493 & 10,856 \\
\hline 2013 & $-2,496$ & $-16,919$ & $-3,669$ & 18,092 & $-1,992$ & 10,831 & 6,047 \\
\hline 2014 & $-3,130$ & $-19,240$ & $-3,955$ & 20,065 & 3,858 & 14,141 & 9,098 \\
\hline 2015 & $-2,795$ & $-20,237$ & $-4,599$ & 22,041 & 2,646 & 18,699 & 13,526 \\
\hline 2016 & $-4,867$ & $-22,689$ & $-5,347$ & 23,169 & 2,652 & 23,098 & 18,143 \\
\hline 2017 & $-12,621$ & $-31,019$ & $-5,048$ & 23,446 & $-1,946$ & 21,403 & 16,145 \\
\hline 2018 & $-18,130$ & $-36,385$ & $-5,282$ & 23,537 & $-6,118$ & 16,407 & 9,789 \\
\hline
\end{tabular}

Source: Authors' calculations, based on data from the State Bank of Pakistan.

After 2004, the CA deficits have recurred, and with much greater intensity. By 2008, the CA deficit had plunged to near USD14 billion. Two successive IMF programs in 2008 and 2013 lowered the CA deficits into the USD3 billion range till 2015. After that, the CA deficit has kept plunging to its current level of USD18 billion for 2018. With bilateral BOP support of USD5 billion and a new IMF agreement in early 2019 of USD8 billion. These widening deficits on the $\mathrm{CA}$, flows of goods, services and asset incomes have 
been financed by the KA by changes in assets held domestically and abroad, as in equation (1).

The KA comprises the FA plus forex reserves held by the SBP, plus some adjustment:

$\mathrm{KA}=\mathrm{FA}+$ reserves + (net errors and omissions + cap account $)$

The FA in turn comprises net borrowing (B) plus net FDI plus net portfolio investment:

$\mathrm{FA}=\mathrm{B}+\mathrm{FDI}+$ portfolio

Illustratively, Table 4 shows that, for the financial year 2017/18, the CA deficit plumbed -USD18.1 billion, amounting to -5.8 percent of GDP. This was based on a trade deficit in goods and services of -USD3.6 billion; a deficit in asset income, called a balance in primary income, of -USD5.3 billion; and a surplus in remittance income, called a balance on secondary income, of USD2.4 billion.

This CA deficit of USD18.1 billion had to be paid for in 2017/18. Table 5 shows that it was paid for largely by running down reserves by USD6.1 billion, net borrowing from abroad of USD7.3 billion, and net FDI inflows of USD2.8 billion, plus net portfolio inflows of USD2.3 billion. The pattern of CA deficits from 1990 to 2018 has been observed to be small deficits till 2000, four years of surpluses till 2004, followed by much larger deficits to date. Table 5 shows that, till 2004, net FDI was largely under USD1 billion or negative. Net portfolio was also largely under USD1 billion over this period, often much smaller. After 2004, net FDI has been consistently positive and ranging between USD1 billion and USD5 billion. Net portfolio has been yoyoing between positive and negative since 2004, ranging up to USD3 billion. Given this small size of FDI and portfolio, relative to the KA needed to match the CA deficits, that has had to be met by borrowing from abroad and running down reserves.

As the CA deficits have mounted over time, borrowing and running down reserves have mounted with them. During the lower deficits of the 1990s, borrowing ranged up to USD3 billion. The CA surpluses of 2000 to 2004 actually saw repayment of borrowing for seven years around that period. Since then, borrowing has mounted to USD5 billion and then USD7 billion over the last three years. Reserves again were largely added to more regularly from 1990 till after the surpluses of 2000-04. After that, reserves 
have been run down more often, mounting to losses of more than USD8 billion over the last two years.

Table 5: Decomposition of the KA (USD million)

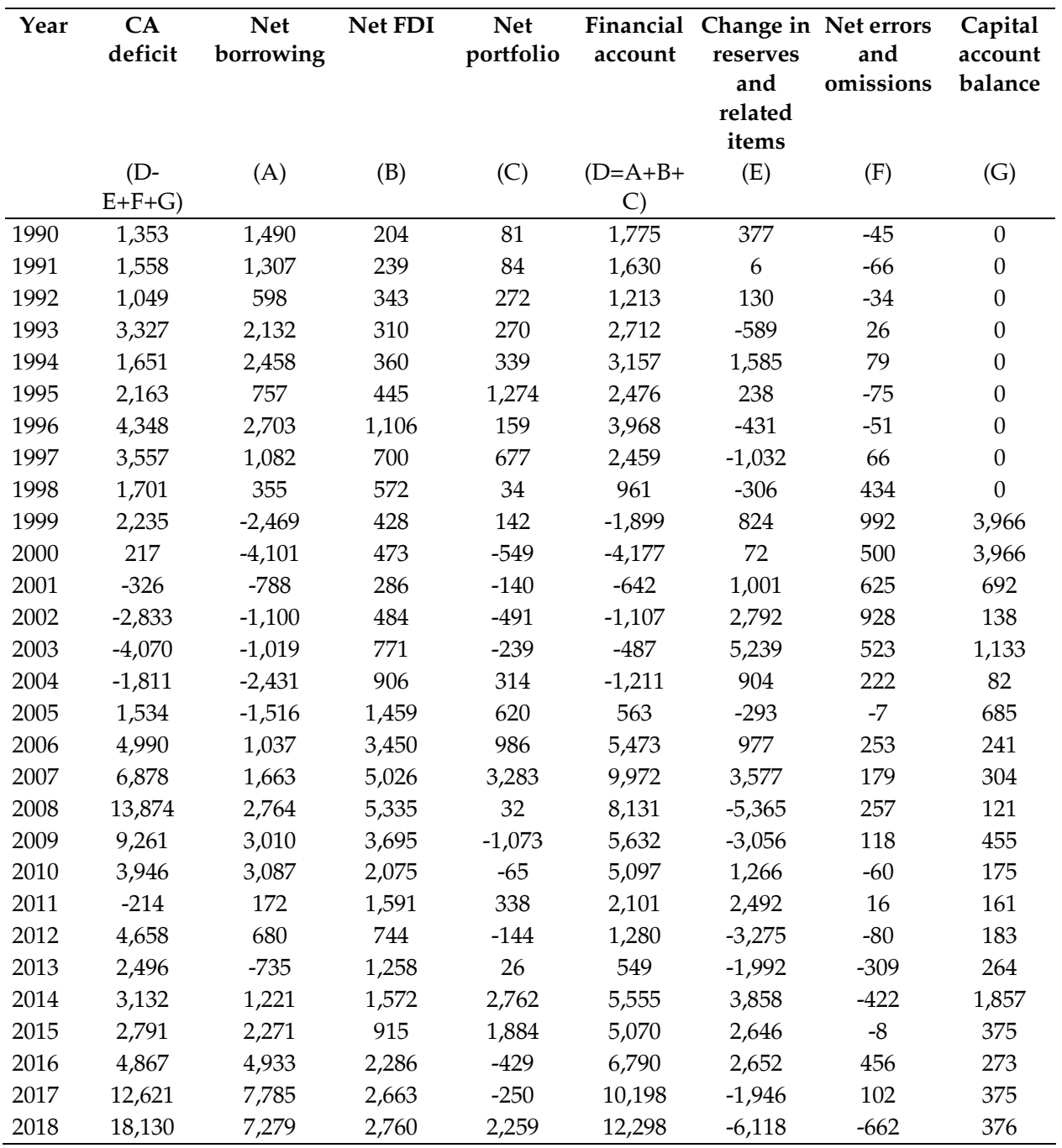

Source: Authors' calculations, based on data from the State Bank of Pakistan.

\subsection{Depreciation Has Been the Panacea}

Over this period from 1990 to 2018, the run of CA deficits has been countered by the price policy of depreciation. Table 3 and Figure 2 show that the rupee has depreciated from PKR 22 to the US dollar in 1990, to PKR110 by 2018. Between mid-2018 and mid-2019 alone, the rupee further slumped to PKR160 to the US dollar. Figure 2 shows that the only plateau in this 
depreciation occurred between 2002 and 2007, which is wrapped around the four years that the CA was in surplus. The rupee's depreciation peaked at PKR61 to the US dollar in 2002. From 2002 to 2004, the CA posted the only large surpluses ever, of USD2 billion to USD4 billion. During this period, the rupee appreciated marginally to PKR58 to the US dollar by 2004, after which the rupee began depreciating again, to reach PKR61 to the US dollar by 2007.

Figure 2: Exchange rate trend (USD to PKR)

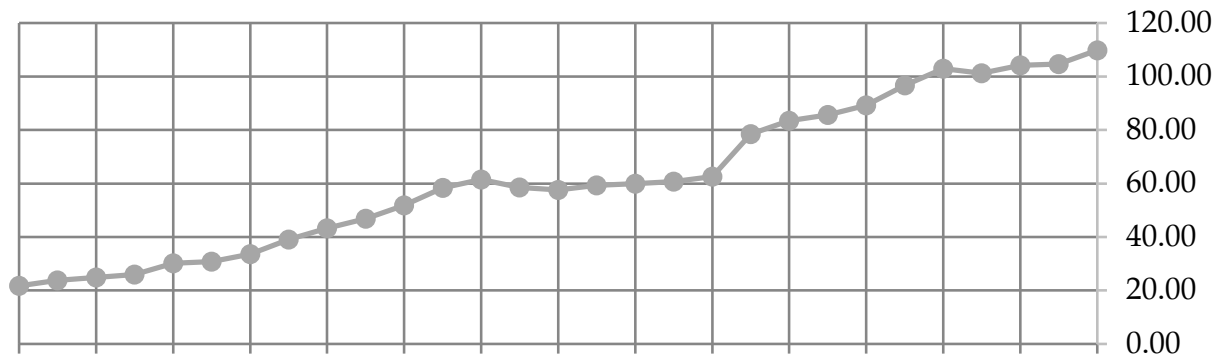

199019921994199619982000200220042006200820102012201420162018

- Exchange Rate (Rs to 1 USD)

Source: Authors' calculations, based on data from the State Bank of Pakistan.

Thus, the pattern has been one of sharp depreciation of the rupee183 percent between 1990 and 2002 — with a hiatus and plateau between 2002 and 2004, down to 165 percent, when the CA ran a surplus. Subsequently, depreciation resumed at an even higher rate-to 406 percent by 2018.

Our theoretical argument is that such a policy of depreciation may or may not work on the CA side of the equation to bring about a price-led equilibrium between exports and imports. However, on the KA side of the equation, such a price-led policy of depreciation will certainly not bring about the equilibrium of the exchange rate. The argument is that a policy of depreciation will, in turn, generate expectations in agents of further depreciation-dubbed here depreciationary expectations, analogous to inflationary expectations. These depreciationary expectations will be triggered by the initial depreciation, causing a drop in domestic profitability vis-à-vis foreign profitability. This will cause net outflows to increase, to benefit from the relative increase in foreign profitability.

As net outflows increase on the KA side of the equation, this will reduce demand for domestic assets relative to the demand for foreign assets on the CA side, lowering domestic price levels and, in turn, depreciating the exchange rate further. The downward spiral is caused by an initial depreciation, resulting in relatively lower domestic profitability and thus an 
increase in net outflows, lower demand for domestic assets, and lower domestic prices, thereby depreciating the exchange rate further; this spiral will not allow an equilibrium of the exchange rate. Thus, a purely price-led policy of depreciation will, on its own, ceteris paribus, give rise to pernicious depreciationary expectations on the KA side of the BOP equation and not allow an equilibrium of the exchange rate.

This theory of depreciationary expectations now needs to be tested for Pakistan's data.

\subsection{Depreciation and Outflows}

Hypothesis 1: Depreciationary expectations will be indicated by the longrun trend of depreciation of the exchange rate being positively correlated with capital outflows from Pakistan.

H1a: This applies to a narrower definition of outflows, comprising domestic net total outflows for investment from the KA, plus the balance on primary income from the CA side, the argument being that both pressureand so weaken-the exchange rate.

H1b: This applies to the broader definition of outflows, comprising the narrower definition of outflows plus RFCAs. The argument is that RFCAs are maintained not just for investment motives, but also for precautionary motives and store of value. Therefore, outflows are now considered to be motivated by speculation, precaution, and store of value. However, the net result expected of these outflows for all three purposes is to pressure and weaken the exchange rate.

Figure 3: Depreciation with total net outflows (USD million)

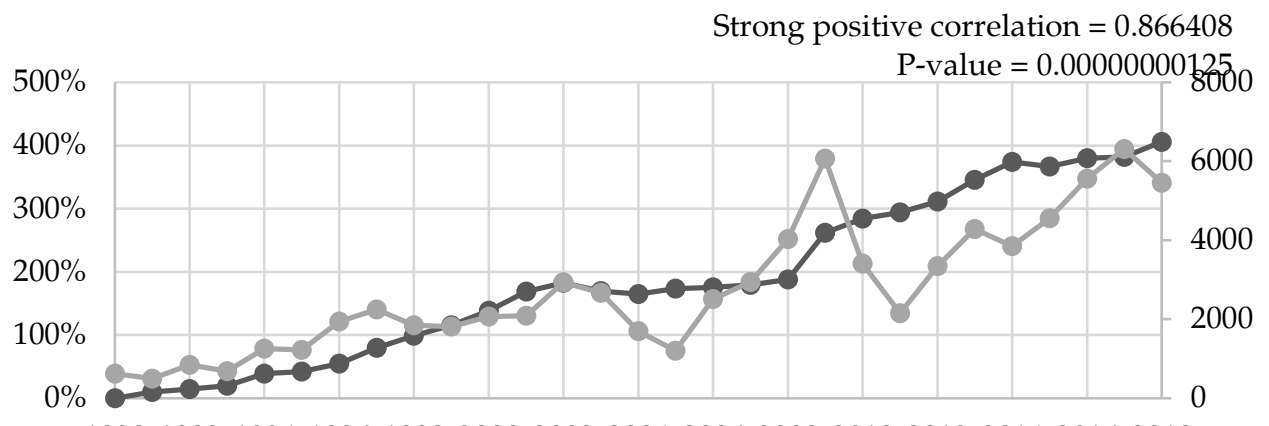

199019921994199619982000200220042006200820102012201420162018

- -Dep Base year 1990 —Total Net Outflows

Source: Authors' calculations, based on data from the State Bank of Pakistan. 
Table 2 and Figure 3 present the estimated series for the narrower definition of outflows, called total net outflows. This comprises the estimated net outflows from the KA side, plus net outflows of primary income from the CA side. Figure 3 shows that total net outflows have clearly increased on trend, from about USD1 billion in 1990, to peak at USD6 billion by 2017. There have been only two troughs in the outflows: (i) over 2003-05, when depreciation also plateaued; and (ii) over 2009-11, when depreciation continued. There appears to be only one episode of depreciation and outflows running contra-trend, against the expectation of the theoretical argument. Otherwise, depreciation and outflows move together positively, as expected in $\mathrm{H} 1$.

Figure 3 shows a strong positive correlation, with 87 percent of the variation in outflows explained by the variation in depreciation. The $p$-value shows the correlation to be highly significant, confirming $\mathrm{H} 1 \mathrm{a}$ for the narrower definition of outflows. The broader definition of outflows comprises the narrower definition plus RFCAs. Table 3 and Figure 4 present the series for this data.

\section{Figure 4: Depreciation with RFCA (USD million)}

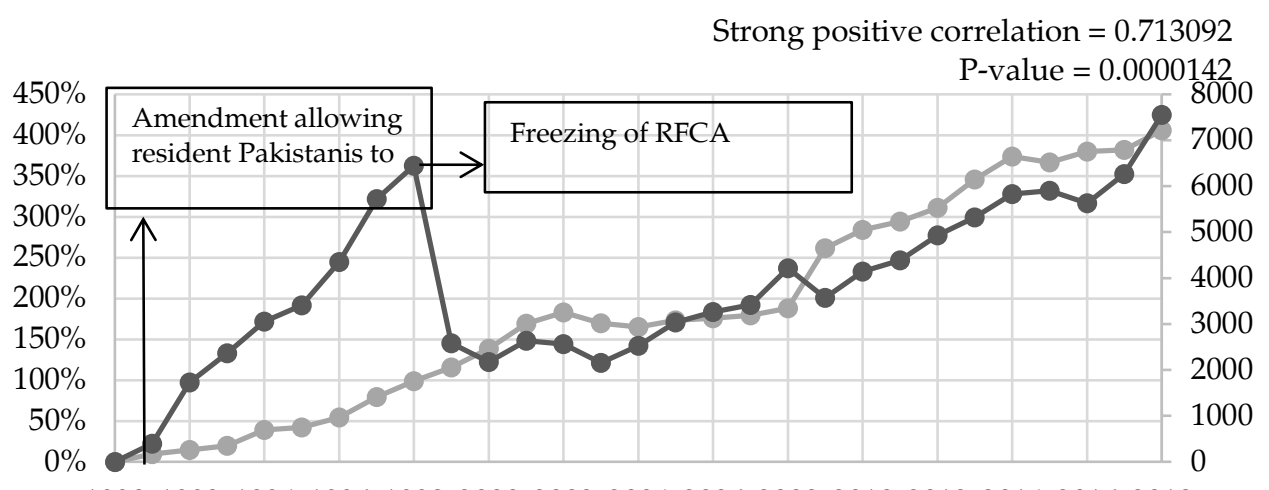

199019921994199619982000200220042006200820102012201420162018

—Dep Base year $1990 \multimap$ RFCA

Source: Authors' calculations, based on data from the State Bank of Pakistan.

RFCAs were legally instituted in 1973, but with a fee charged for maintenance. Table 3 shows them to be negligible in volume till 1992 when the fee was removed. These RFCAs boomed till 1997 when the regime was confronted by peaking CA deficits, requiring unprecedented levels of foreign borrowing of USD4 billion a year as Table 5 shows, and the first major rundown of reserves of USD1 billion. In 1998, the regime finished off 
convertibility by freezing RFCAs, allowing only rupee withdrawals, with a host of administrative permissions and fees instituted for customers who wished to continue.

Table 3 shows that this government seizure of RFCA forex drove down their volume from a peak of USD6.5 billion in 1998 to USD2 billion for the next few years. The government allowed new RFCAs to be opened with restored convertibility, but it took several years for the disincentive of the 1998 freeze and seizure of forex to wear off. Since 2004, however, the volume in RFCAs has mounted to a high of USD7.5 billion by 2018. Our argument is that these RFCAs also constitute an increase in demand for forex and, therefore, a reduction in demand for rupees, which weakens the rupee. Accordingly, RFCAs should count as outflows. The hypothesis is that this broader definition of outflows is expected to be correlated with depreciation.

Figure 4 shows that RFCAs on their own have moved together with depreciation. With depreciation, agents will hedge against the rupee, especially for store of value. There is a strong positive correlation, with 71 percent of the variation in RFCAs being explained by the variation in depreciation. The correlation has a highly significant p-value. Table 3 and Figure 5 add RFCAs to total net outflows for the broader definition of outflows. These are seen in Table 3 to mount up from USD0.6 billion in 1990 to USD13 billion by 2018 .

\section{Figure 5: Depreciation with sum of total net outflows and RFCA (USD million)}

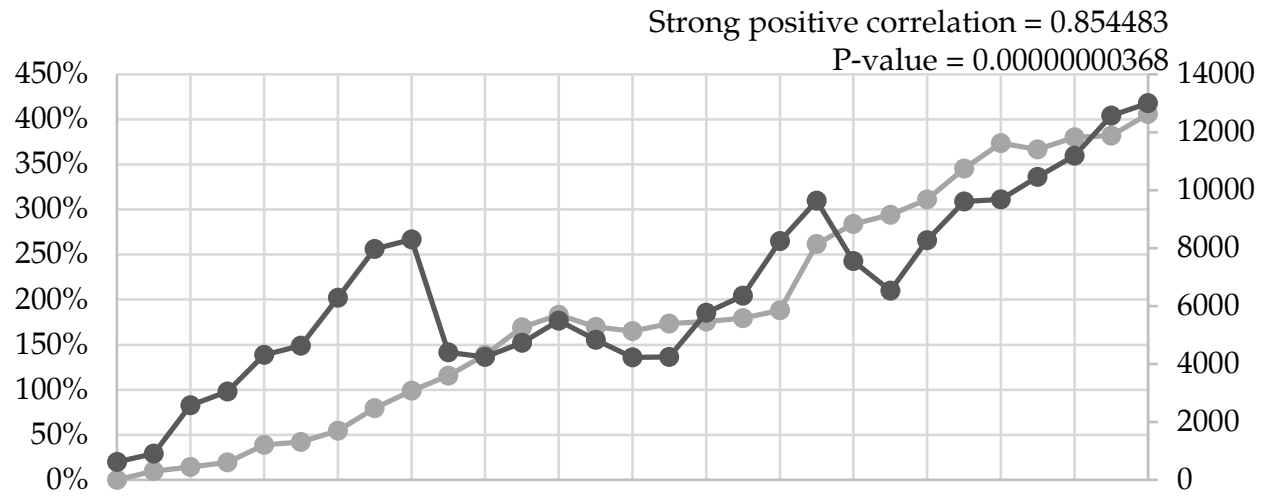

199019921994199619982000200220042006200820102012201420162018

$\longrightarrow$-Dep Base year $1990 \longrightarrow \sum$ of Total Net Outflows and RFCA

Source: Authors' calculations, based on data from the State Bank of Pakistan. 
Figure 5 shows that this wider definition of outflows and depreciation move together. There is a strong positive correlation, with 85 percent of the variation in the broader definition of outflows being explained by the variation in depreciation. The correlation has a highly significant $\mathrm{p}$-value.

\subsection{Depreciation Does Not Lead to an Equilibrium Exchange Rate}

H2: In a price-led equilibrium model, depreciation of the exchange rate will not find equilibrium. Equilibrium implies some cyclicality of the exchange rate or at least some stationarity after downfalls. In Pakistan's case, lack of equilibrium will lead to a long-run secular decline in the exchange rate over time.

The ideal observation of price equilibrium is the cobweb theorem, where the price oscillates around a particular value. However, to depict a drop in price, leading to equilibrium between supply and demand, a better characterization would be stationarity after a fall—an L curve. Or, if we are depicting depreciation as an increase in the rupees needed per, say, US dollar, as we are here, then stationarity should describe a $\rho$ curve-an increase in the number of rupees per USD, followed by stationarity or cyclicality around a new equilibrium value. Even if periodic depreciation is needed to obtain a cycle of disequilibrium and equilibrium, followed by another cycle of disequilibrium and equilibrium, then we should be able to observe periodic $\rho$ curves.

Alternatively, if periodic depreciation is not leading to periodic equilibrium, then we should observe a secular depreciation over time, according to H2. What Figure 2 shows is a secular depreciation of the rupee against the US dollar over the very long period of 28 years, from 1990 to 2018. This decline is interrupted by one stationarity between 2002 and 2004, when the rupee appreciated from PKR61 to PKR57 against the US dollar, before depreciating again from 2005 onward. Surely, price policy to generate equilibrium is not meant to act over decades, allowing the 2002-to-2004 stationarity, or $\rho$, to be interpreted as oscillation around one equilibrium in 38 years. Rather, the interpretation of Figure 2 should be as a secular depreciation over the very long run of 38 years, with no periodic oscillations or $\rho$ curves around periodic equilibriums. This lack of observation of periodic oscillations or $\rho$ curves, as evidence of lack of periodic equilibriums, confirms $\mathrm{H} 2$ - that a price-led equilibrium model does not allow depreciation of the exchange rate to find an equilibrium value. 
Another test of whether depreciation can even theoretically lead to equilibrium of the exchange rate in Pakistan's case is afforded by observing whether depreciation leads to a reduction in the CA deficit. This should be the case according to textbook equation (7), where net exports are a negative function of the exchange rate. If depreciation does tend to lower the CA deficit, then we are, in theory, moving toward an equilibrium value of the exchange rate. If depreciation does not tend to lower the CA deficit, then we are not even headed toward finding an equilibrium value of the exchange rate.

Figure 6 plots the increasing value of the depreciation index, with the clear upward trend well observed by now. It also plots the CA, which shows a long-run downward trend over 38 years from 1990 to 2018. In the long run, even a gradual depreciation of the exchange rate has not lowered the CA deficit.

\section{Figure 6: Depreciation with CA (USD million)}

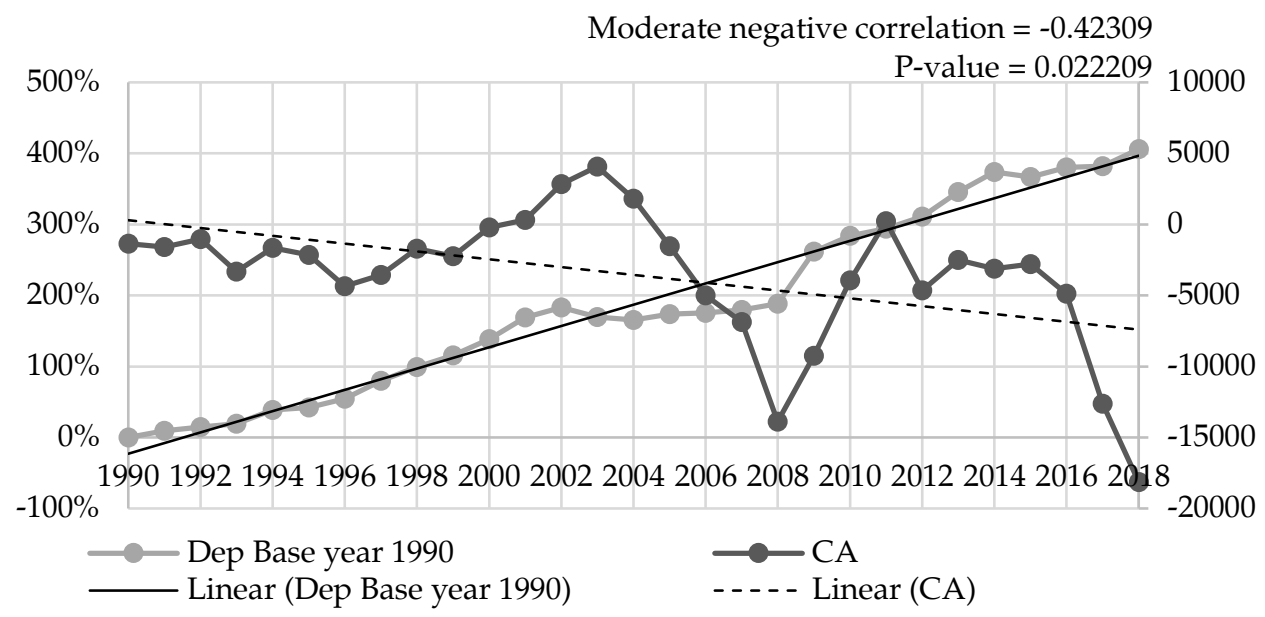

Source: Authors' calculations, based on data from the State Bank of Pakistan.

The only years for which depreciation plateaued, 2002 to 2004, was when the CA was also briefly in surplus in these 38 years. Apart from those four years, depreciation has not reduced the CA deficit between 1990 and 2018. This further supports the theory we have put forward of the pernicious nature of depreciationary expectations: that an initial depreciation of the exchange rate will lead to expectations of further depreciation. The trigger for these deflationary expectations is the loss in domestic profitability relative to foreign profitability, and increasing capital outflows to take 
advantage of relatively higher profits abroad. These outflows have been observed above to be well correlated to depreciation.

The outflows raise the demand for foreign assets, lowering the demand for domestic assets, inducing in turn further depreciation. This implies a vicious cycle of depreciation, relatively lower domestic profitability, increased outflows, and lower demand for domestic assets, resulting in further depreciation. This further implies that a price-led policy of depreciation will not result in equilibrium of the exchange rate.

We observe empirically evidence of the beginning and end processes of this lack of equilibrium. We observe depreciation leading to capital outflows, but discern no periodic stationarity or $\rho$ curves, as evidence of periodic equilibrium. Ergo, the study so far supports the theory put forward of deflationary expectations preventing a price-led equilibrium in the exchange rate. We now need evidence of the major causal factor triggering the outflows, which is the depreciation-led fall in domestic profitability relative to foreign profitability. This should imply that outflows of capital reduce domestic investment and is tested next.

\subsection{Depreciation Will Lead to Capital Outflows, Reducing the Share of Investment in GDP}

H3: Depreciationary expectations will increase capital outflows from Pakistan, which in turn will reduce domestic investment in Pakistan. Hence the long-run trend of depreciation will be negatively correlated with the share of private investment in Pakistan. ${ }^{4}$

Expectations of depreciation by private agents-investors-can be expected to lead to increased capital outflows, to take advantage of increased profitability abroad compared to profitability in Pakistan. These increased outflows have been well observed to be correlated with increased depreciation, nor do depreciationary expectations allow an equilibrium in the exchange rate. Again, this has been well observed above. Increased capital outflows, comprising both domestic capital as well as repatriation of asset incomes earned by foreigners-both of which could have been invested in Pakistan-implies that the rate of domestic investment could drop in the long run. This underscores the expectation in H4, that

\footnotetext{
${ }^{4}$ The mechanism works through the availability of foreign exchange. Domestic banks can always provide credit even in the absence of savings, which means obtaining foreign saving, i.e., foreign borrowing.
} 
depreciation will be negatively correlated with the share of private investment in Pakistan.

Table 3 and Figure 7 give the share of gross private investment in GDP from 1990 to 2018. Figure 7 shows a clear downward trend in the investment share, from 20 percent in 1990 to about 16 percent by 2018, while depreciation has been increasing on trend over this period. This gives a strong negative correlation between the investment share and depreciation. About 59 percent of the variation in the share of investment in GDP is explained by the variation in depreciation. The $\mathrm{p}$-value is highly significant.

Depreciation cannot be the definitive and comprehensive causal factor for the declining long-run trend in the investment share. Figure 7 does not portray itself as the long-run investment function for the country. Obviously, a number of other factors have to be used to explain the declining investment share. However, the contribution of depreciation to the declining investment share is significant.

\section{Figure 7: Depreciation with gross total investment as a percentage of GDP}

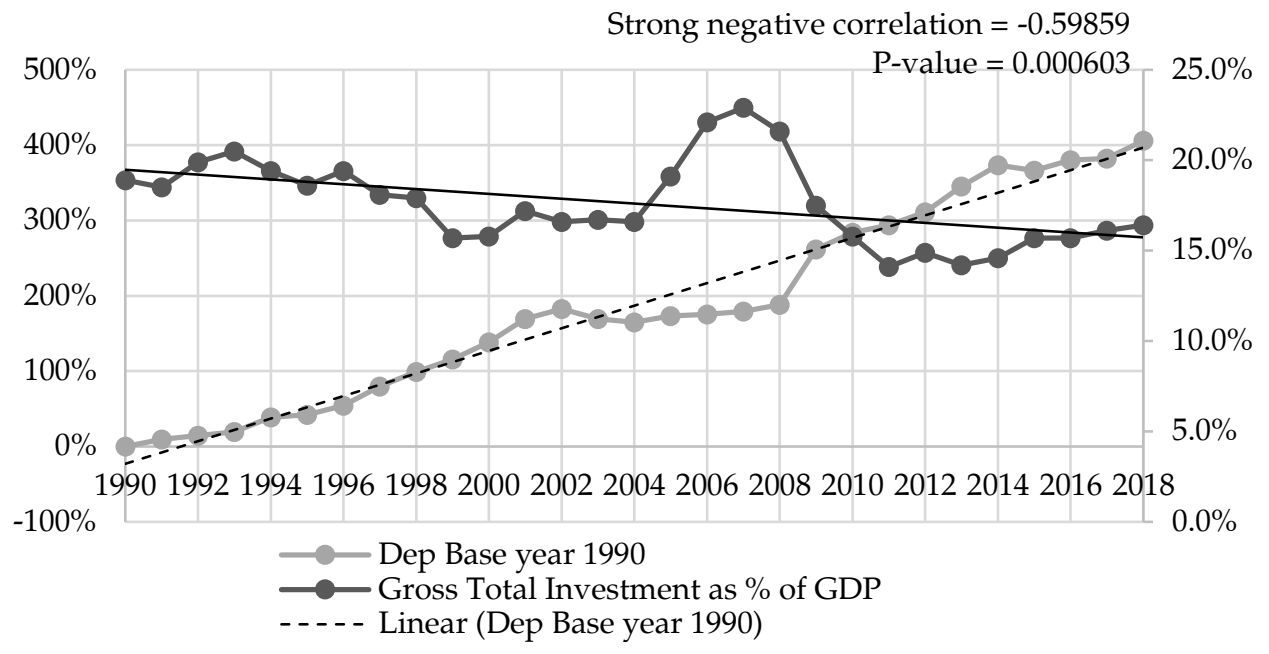

Source: Authors' calculations, based on data from the State Bank of Pakistan.

The period 2002-07 is particularly illustrative of the observed negative correlation between the investment share and depreciation. This is the only period in Figure 7 when depreciation plateaus or lowers. It is also the only period when the investment share surges to 22 percent, contra the long-run declining trend. This is good evidence in support of our argument 
that the relative stability in the exchange rate over this period reduced expectations of further depreciation. This kept domestic profitability relative to foreign profitability constant, inspiring a surge in domestic investment.

\subsection{Depreciation Will Lead to Capital Outflows, Reducing the Share of Savings in GDP}

H4: Deflationary expectations will increase capital outflows from Pakistan, which in turn will reduce domestic savings in Pakistan. Hence, the long-run trend of depreciation will be negatively correlated with the share of private savings in Pakistan.

Underlying the declining share in private investment should be a declining share in private savings. Depreciation, followed by expectations of further deflation by private agents, can be expected to lead to capital outflows to invest domestic savings abroad, to benefit from the relative increase in profitability abroad compared to Pakistan. We have used two definitions of capital outflows. A narrower definition comprises just domestic outflows for investment, plus repatriation of foreign asset income. A broader definition adds to the narrower definition of capital outflows, RFCAs held in Pakistan, the argument being that both the narrower definition of capital outflows and the RFCAs pressure and weaken the exchange rate.

The motive for RFCAs was taken to be not speculative, but instead store of value and precaution. Thus, the addition of these two motives to the motive of speculation adds, of course, to the quantum estimation of capital outflows. However, the additional motives of store of value, precaution, and consumption, should raise consumption and lower savings. Therefore, the broader definition of capital outflows, because of its added motives of store of value and consumption, by raising the consumption share should have a greater impact on the savings share. That is, depreciation should have not only a negative impact on the savings share, but it should also be stronger than its impact on the investment share.

Table 3 and Figure 8 show the series for savings as a share of GDP from 1990 to 2018. The figure plots savings falling clearly on trend, from 17 percent of GDP in 1992 to 8 percent of GDP by 2018. With the well-observed increasing trend in the quantum of depreciation, this gives a strong negative correlation with the savings share. More than two thirds of the variation in the savings share is explained by the variation in depreciation. 
The correlation for the savings share is stronger than the correlation for the investment share. The caveat for the investment result must be repeated for the savings result. Figure 8 cannot be a comprehensive savings function, which comprises other key macro aggregates. However, it is indicative of the impact of depreciation as a contributory factor explaining the declining trend in the savings share. Again, illustratively, as for the investment correlation, the period of plateauing in depreciation between 2002 and 2007 also shows a corresponding bump-up in the savings share, contra the declining long-run trend.

\section{Figure 8: Depreciation with domestic savings as a percentage of GDP}

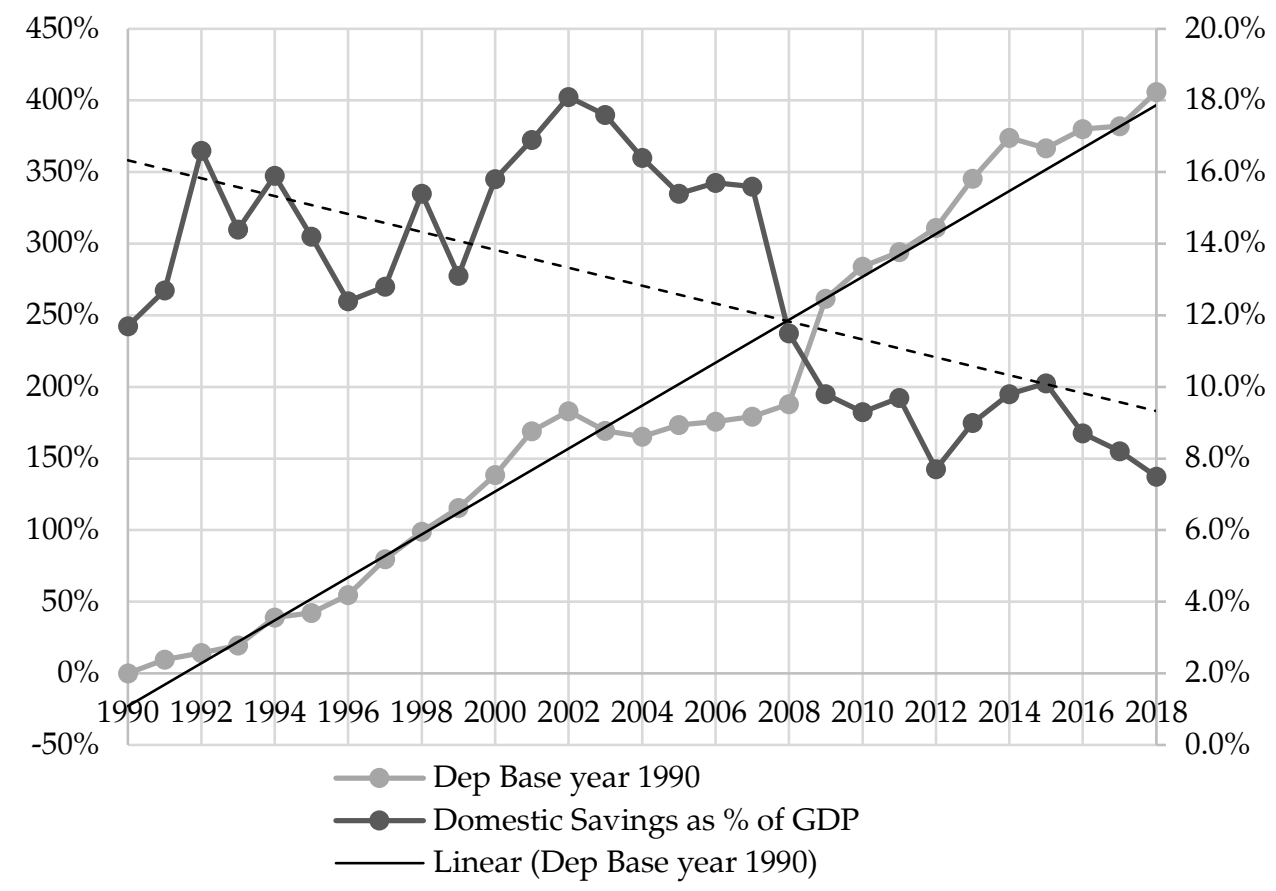

Source: Authors' calculations, based on data from the State Bank of Pakistan.

\section{Conclusions for Policy}

This section concludes our paper with several key policy implications. 


\subsection{The Theory of Depreciationary Expectations}

We have some statistical evidence to support the proposed theory of depreciationary expectations operating in Pakistan, observed over the longrun period of 1990 to 2018. The theory of depreciationary expectations put forward in this article argues that a significant and protracted CA deficit will not be closed through a purely price-based policy instrument of depreciation of the exchange rate. This is because such a price solution (depreciation of the exchange rate) is meant to operate on the CA by lowering the price of exports, raising their volume, while increasing the price of imports, but lowering their volume, thus reducing the CA deficit.

This is a partial equilibrium analysis, focusing solely on the CA side of the equation, whereas the BOP deficit on the left-hand side has to be paid for out of the KA given by the right-hand side of the equation. A BOP deficit only balances, since it is paid for by claims on assets given on this KA. The deficit on the CA is paid for on the KA by net capital inflows into the country, liquidating country assets owned abroad, running down forex reserved held by the SBP, and borrowing from abroad.

Depreciation of the exchange rate follows at least some logic of giving an equilibrium on the left-hand side of the equation, on the CA. However, depreciation will not lead to an equilibrium of the exchange rate on the right-hand side of the equation, on the KA. This is because depreciation of the exchange rate will lead to expectations by private agents, domestic and foreign investors, and domestic consumers, of further depreciation.

The causal factor for depreciationary expectations is that the initial depreciation of the exchange rate reduces domestic profitability relative to foreign profitability. We have demonstrated above axiomatically that, in a two-factor case, the depreciation of the exchange rate, working to reduce the real wage, will increase profitability, but be canceled out by the equal depreciation of rupee profits in, say, US dollar terms. Further, in a more realistic three-factor case where some plant and capital equipment is imported, depreciation will now raise this cost in US dollar terms, resulting in a net loss in domestic profitability relative to foreign profitability.

Investors, both domestic and foreign, will then increase capital outflows and reduce capital inflows, raising net capital outflows to benefit from the relative increase in profitability abroad. The increase in net capital outflows will further weaken and depreciate the exchange rate. The 
increased outflows also lower demand for domestic assets relative to an increased demand for foreign assets, which puts further downward pressure on the exchange rate.

Thus, depreciationary expectations characterize a vicious cycle of depreciation, falling domestic profitability compared to foreign profitability, rising net capital outflows, and falling demand for domestic assets, leading back in turn to further depreciation of the exchange rate, which implies that there will be no equilibrium of the exchange rate on the KA side of the equation. While a partial equilibrium analysis of just the CA may possibly give equilibrium on the left-hand side of the equation, it cannot give equilibrium of the exchange rate on the $\mathrm{KA}$, on the right-hand side of the equation. That is, a GE analysis of both the CA and KA does not give a pricedetermined equilibrium of the exchange rate.

The increase in net capital outflows may be initiated by the speculative motive but is added to by motives of store of value, precaution and consumption. Savers and consumers will also want to increase their holdings of forex rather than rupees through RFCAs. The increased demand for forex rather than rupees will further weaken the latter. Thus, RFCAs also behave like net capital outflows in weakening the rupee and contributing to deflationary expectations. This model of depreciationary expectations captures Pakistan's current and indeed recurrent BOP crises. Evidence marshalled for the KA for Pakistan for the years 1990 to 2018 shows significant support for this theory of depreciationary expectations.

\subsection{The Evidence Supporting Depreciationary Expectations}

We have distilled the theory of depreciationary expectations into four hypotheses, each of which is supported by statistically significant evidence. One, depreciationary expectations imply that net capital outflows will increase with the quantum of depreciation of the rupee. A narrower definition of capital, comprising domestic outflows for investment plus repatriation of nonresident asset income earned domestically, shows a strong positive correlation that is highly significant. A broader definition of capital adds to the narrower definition RFCAs and, again, shows a strong positive correlation that is highly significant.

Further research could try to establish Granger causality between depreciation and outflows. However, our study establishes that both have been locked in a vicious cycle of spurring each other on in Pakistan over the last 30 years. This implies that the second hypothesis, that a purely price- 
based policy of depreciation on its own will not lead to an equilibrium in the exchange rate. Equilibrium implies that depreciation would result in some stationarity, if not cyclicality, around a new equilibrium value of the rupee. Over the period under observation, from 1990 to 2018, we would expect to see a number of these cycles. However, we observed just one period of stationarity of the rupee, over 2002-04, which coincided with the only CA surplus in these 30 years. Thus, while the rupee has been consistently devalued by some 400 percent over this long period, stationarity was achieved only once. This cannot be interpreted as equilibrium of the rupee. Rather, it must be interpreted as lack of equilibrium.

We therefore conclude on this evidence that a purely price-based policy of depreciation of the exchange rate has not led to an equilibrium value for the rupee because depreciationary expectations were consistently generated in the economy. These depreciationary expectations have induced increases in net capital outflows, which in turn have depreciated the rupee further, completing a pernicious cycle between depreciation and net capital outflows. The increase in net capital outflows triggered by continuous depreciation of the rupee can be expected to reduce domestic investment and savings, according to the third and fourth hypotheses. That has indeed been the case. Private investment shows a long-run trend downward over this period from 18 percent of GDP to 16 percent, strongly negatively correlated with the quantum of depreciation. Savings similarly drop from 17 percent of GDP to under half, to 7 percent-again, strongly negatively correlated with the quantum of depreciation.

While these are by no means comprehensive investment and savings functions, requiring other macro-aggregates to estimate them, they do show the major implication of a purely price-based policy of depreciation, working though depreciationary expectations, to induce an increase in capital outflows, so contributing to the secular decline in domestic investment and savings.

\subsection{Policy Implications}

Macro-policy in Pakistan must then tread the proverbial slippery slope. The policy option of depreciation on its own is self-contradictory because it triggers depreciationary expectations. The initial depreciation causes domestic profitability to drop compared to foreign profitability, leading to increased outflows. The policy option to counter this relative drop in domestic profitability is to raise the domestic interest rate. The resulting restoration of domestic profitability relative to foreign profitability will 
reduce net outflows, which in turn will reduce further depreciation of the exchange rate. An increase in domestic interest rates can contain the depreciationary expectations triggered by an initial depreciation of the exchange rate. However, raising interest rates reduces investment and so growth-especially for Pakistan's economy with an already very weak investment rate of 16 percent of GDP. Raising interest rates will further weaken growth below its already anemic 4 percent per annum.

A third policy option is therefore implied to fix the BOP crisis, prevent outflows, prevent deflationary expectations, and maintain investment and growth: the option of capital controls, with a now established history of efficacy.

\subsection{Capital Controls}

Capital controls to manage BOP crises are time-honored, to prevent the great mischief which the realm suffereth when gold and silver leave the country. So saying, Richard II imposed laws to make it difficult to export precious metals from England in 1381. These prohibitions were lifted only 150 years later under Henry VIII. Come the Great Depression and disruption of the gold standard, John Maynard Keynes argued successfully for permanent restrictions on cross-border capital flows, which in 1944 the Bretton Woods Conference baked in. Capital controls fell out of favor of the economic orthodoxy when the Bretton Woods system collapsed at the end of the 1960s, fixed exchange rates were abandoned, and over the next couple of decades, the IMF argued that capital should flow freely across borders (Bordo, 2017).

That reversal too has been overturned. With the Asian crisis, Malaysia under Prime Minister Mahathir spurned the IMF and imposed capital controls to great effect. Iceland followed when its banking crisis led investors to pull money out of the country. Cyprus used capital controls for two years for its banking crisis in 2013 (Weaver \& Stothard, 2013). Greece's monumental debt crisis verging on default and near crashing out of the Euro, led to stringent capital controls to prevent outflows. These were sanctioned by the European Commission and the IMF as part of the USD200 billion-plus bailout from 2015 to date. The IMF shifted its stance and declared in 2010 that capital controls could be useful. China, with USD3 trillion in reserves, has a managed float of the yuan just breaking 7 to the US dollar, and strict capital controls on outflows, down to caps on ATMs abroad (Song, Storesletten, \& Zilibotti, 2014; Clover \& Weinland, 2017). 


\subsection{Macro-Policy for Pakistan}

Pakistan should focus on just the need to maintain three macrofundamentals: the exchange rate, already pressured downward in open markets; the inflation rate, stoking up with low growth; and the interest rate, which has to be raised to control inflation and keep the exchange rate peg from falling further. However, this rise in the interest rate is also the cost of borrowing and thus reduces investment and growth. This is the oft-cited Fleming trilemma of macro policy.

Most countries' economic regimens go to great lengths to control these macro-fundamentals, not allowing them to slip by default, except through planned policy. Otherwise, markets get spooked, the exchange rate slumps, inflation spikes, and a much higher cost has to be paid in raising the interest rate to counter these contrary movements. Thus, the new regime's first big misconception has been the thought that it had time on its side to search for bilateral support for its BOP. The bilateral support of USD5 billion parked temporarily with Pakistan has taken eight months and not eased the pressure on macro-fundamentals. If anything, the time taken has weakened these macro-fundamentals further.

The IMF stand-by arrangement should have been negotiated long before to avoid the valuable slipping in macro-fundamentals for which a much higher price now has to be paid. The higher price of the just-inked draft agreement with the IMF is the surrendering of the exchange rate. The peg of the rupee has been abandoned for a free float. This is bad economics for a country in Pakistan's fragile economic position because only a few high-income countries have full free floats, for instance, the US, the UK, Canada, and Argentina.

Predominantly, countries have pegs of some sort-also called managed floats-for three major reasons. One, for a beleaguered economy such as Pakistan's at the moment, a free float will set in expectations of further depreciation of the exchange rate. People will rationally bet against the rupee for motives of speculation and preserving real value with flight of capital abroad or into another currency, both weakening the rupee further. One could call them depreciationary expectations-analogous to inflationary expectations.

Two, a free float, with a depreciating exchange rate, will increase the rupee price of Pakistan's external commitments-payments that have to be 
made abroad, repayments of loans, debt, and future credit. The country will not be any forwarder.

Three, and perhaps even more fundamental, a free float brings complete uncertainty into the price environment that investors face. Investors need certainty in the prices of their inputs and outputs to determine their rate of return. However, downward pressure-more a free fall of the exchange rate-will import inflation into domestic prices and the rupee value of all imports will skyrocket. It is not just the upper classes that will have to forgo their French cheeses, but also the price of imported capital equipment, plant and machinery that will become prohibitive. Pakistan produces hardly any capital equipment domestically, and thus the rising cost of imported capital goods will further inhibit an already weak domestic investment and growth rate.

Additionally, the inflationary effect on domestic prices through a free float and depreciating exchange rates can be huge. Imagine the rising price of energy used to produce all goods, especially wage goods for the poor. The real wage will fall. What this is tantamount to is that the rupee is being depreciated to reduce the real wage to give exporters an easy way to increase their exports rather than through increased competitiveness and productivity. As such, this policy stands to raise poverty levels far more than any added welfare programs can ameliorate. Welfare programs too have to begin with getting the macro-policies right rather than just handouts, no matter how well intentioned.

What then are the alternatives? If anything needs revising in the agreement with the IMF, it is the free float of the exchange rate. A peg of the rupee to a foreign currency or basket of currencies must be sought as of yore. There should not be just binary reliance on one policy instrument to sort out Pakistan's predicament on its external account. A judicious use across three policy instruments would be better.

One, a peg with some depreciation can be negotiated, but not a further massive depreciation that ushers in all the expectations of further depreciation and the entailed problems of domestic and foreign speculators betting against the rupee, with outflows and moves into forex. Two, Pakistan could maintain the peg with some reliance on an interest rate hike-but, again, not a massive hike, to keep some growth in the economy. The currently envisaged 2 percent hike above the prevalent rate of 10.75 percent is quite reasonable, certainly compared to Turkey's hiking of interest rates to 25 percent (Pooley, 2018). In fact, in a tradeoff between depreciating the 
exchange rate and appreciating the interest rate, there could be more reliance on the interest rate. Three, and most importantly, some form of capital controls is needed to counter the deflationary expectations that have been set in, to counter the betting against the rupee and capital flight abroad. Certainly, if economies such as China with USD3 trillion in reserves or India with half a trillion dollars have resorted to capital controls, can Pakistan with barely USD10 billion afford not to? 


\section{References}

Abdelal, R., \& Alfaro, L. (2003). Capital and control: Lessons from Malaysia. Challenge, 46(4), 36-53.

Amjad, R. (2019, March 27-28). Breaking out of Pakistan's stop-go economic cycles: Does the fiscal deficit hold the key 1999-2019? [Conference paper]. 15 th Annual Conference on the Management of the Pakistan Economy, Lahore School of Economics.

Bordo, M. D. (2017). The operation and demise of the Bretton Woods system; 1958 to 1971 (Working Paper No. 23189). National Bureau of Economic Research.

Borensztein, E., \& De Gregorio, J. (1999). Devaluation and inflation after currency.

http:/ / citeseerx.ist.psu.edu/viewdoc/download?doi=10.1.1.202.9 $25 \&$ rep $=$ rep $1 \&$ type $=$ pdf

Chaudhry, A., \& Andaman, G. (2014). The need for a coordinated industrial strategy to boost Pakistani exports: Lessons from Asia. Lahore Journal of Economics, 19, 177-206.

Clover, C., \& Weinland, D. (2017, January 8). China capital controls help slow cash outflows. Financial Times. https://www.ft.com/content/02ab9faa-d595-11e6-944be7eb37a6aa8e.

Dabrowski, M. (Ed.). (2012). Currency crises in emerging markets (pp. 36, 69, 77, 81-82). Springer.

Gopinath, G. (2017, October 12-13). Rethinking macroeconomic policy: International economy issues [Conference paper]. Rethinking Macroeconomic Policy, Peterson Institute for International Economics, Washington, DC.

Gopinath, G. (2019). Rethinking international macroeconomic policy. In O. Blanchard \& L. H. Summers (Eds.), Evolution or revolution? Rethinking macroeconomic policy after the great recession (pp. 271-298). MIT Press.

Hamid, N., \& Mir, A. S. (2017). Exchange rate management and economic growth: A brewing crisis in Pakistan. Lahore Journal of Economics, 22, 73-110. 
International Monetary Fund. (2009). Balance of payments and international investment position manual (6 $6^{\text {th }}$ ed.) http://www.imf.org/external/pubs/ft/bop/2007/bopman6.htm

International Monetary Fund. (2018). International financial statistics [Database]. https://data.imf.org/?sk=4c514d48-b6ba-49ed-8ab952b0c1a0179b\&sId=1409151240976

Ishtiaq, N., Qasim, H. M., \& Dar, A. A. (2016). Testing the Marshall-Lerner condition and the J-curve phenomenon for Pakistan: Some new insights. International Journal of Economics and Empirical Research, 4(6), 307-319.

Jaffri, A. A., Asghar, N., Ali, M. M., \& Asjed, R. (2012). Foreign direct investment and current account balance of Pakistan. Pakistan Economic and Social Review, 50(2), 207-222.

Khan, S., Azam, M., \& Emirullah, C. (2016). Import demand income elasticity and growth rate in Pakistan: The impact of trade liberalization. Foreign Trade Review, 51(3), 201-212.

Malik, S., Hayat, M. K., \& Hayat, M. U. (2010). External debt and economic growth: Empirical evidence from Pakistan. International Research Journal of Finance and Economics, 44, 88-97.

Obstfeld, M., \& Krugman, P. R. (2003). International economics: Theory and policy. Addison-Wesley.

Pakistan, Ministry of Finance. (2018). Pakistan Economic Survey 2017/18. Government of Pakistan.

Pooley, C. R. (2018, October 25). Turkish interest rates: Has the central bank done enough? Financial Times. https://www.ft.com/content/ 2c0686ee-d778-11e8-ab8e-6be0dcf18713.

Rahim, S. (2020). ${ }^{* *}$.

Rashidin, M. S., Ullah, I., \& Jehangir, M. (2017). The influence of balance of payments and balance of trade on exchange rate in developing countries of Asia: A case study of Bangladesh, Pakistan and India. Sonargaon University Journal, 1(2).

Shahzad, A. (2017). Capital account liberalization and development in Pakistan [Unpublished Master's dissertation]. Lahore School of Economics. 
Song, Z., Storesletten, K., \& Zilibotti, F. (2014). Growing (with capital controls) like China. IMF Economic Review, 62(3), 327-370.

State Bank of Pakistan. (2018). Annual report 2017-18: The state of Pakistan's economy. https://www.sbp.org.pk/reports/annual/arFY18/ Anul-index-eng-18.htm

Umezaki, S. (2019). The Malaysian economy after the global financial crisis: International capital flows, exchange rates, and policy responses. Public Policy Review, 15(1), 69-98.

Valdivia-Velarde, E., \& Razin, T. (2014). BMP6 compilation guide (chaps. 3, 4, 5, 10, 14, appendices 1, 4). International Monetary Fund.

Warnock, F. (2018). A user's guide to the BOP and IIP. Darden School of Business.

Weaver, C., \& Stothard, M. (2013, March 28). Cyprus imposes severe capital controls. Financial Times. https://www.ft.com/content/9901f6ce96f2-11e2-a77c-00144feabdc0.

Zhang, N. (2015, April 16-17). Measuring global flow of funds and integrating real and financial accounts: Concepts, data sources and approaches [Conference paper]. W(h)ither the SNA? IARIW-OECD, Paris. 